\title{
Natural insecticide based-leaves extract of Piper aduncum (Piperaceae) in the control of stink bug brown soybean
}

\author{
Inseticida natural a base de extrato de folha de Piper aduncum (Piperaceae) no controle do \\ percevejo marrom da soja
}

\section{Ludmila Porto Piton ${ }^{\mathrm{I}}$ Leonardo Morais Turchen ${ }^{\mathrm{I}}$ Alessandra Regina Butnariu ${ }^{\mathrm{II}}$ Mônica Josene Barbosa Pereira ${ }^{I^{*}}$}

\begin{abstract}
This research aimed to evaluate the insecticide potential of the leaves extract of Piper aduncum (L.) (Piperaceae) on development of brown stink bug, Euschistus heros (F.), major pest in soybean crop in Mato Grosso State. For this a bioassay was conducted with eggs, nymphs and adults of this stink bug, using the concentrations $0.5 ; 1.0 ; 2.0 ; 4.0$ and $8.0 \%$, of the extract acetonic of $\boldsymbol{P}$. aduncum and acetone for control. It was evaluated the numbers of unviable eggs, nymphs death and longevity, fecundity and fertility of the adults. In the immersing eggs bioassay, all concentrations greater than $1 \%$ unviable more than $70 \%$ of the eggs, while in the contact bioassay only $19 \%$ of the eggs were unviable in $8 \%$ concentration, differing of control. In nymphs bioassay the concentrations of $8 \%$ and $4 \%$ caused death of $72 \%$ and $52 \%$, respectively. In adults bioassay all concentrations tested reduced significantly the survival and reproduction of the insects. Thus is evidence that $\boldsymbol{P}$. aduncum is a potential plant for stink bug control, because it had deleterious action in all development phases on $\boldsymbol{E}$. heros.
\end{abstract}

Key words: pimenta-de-macaco, Euschistus heros, pest soybean, phytoinsecticide.

\section{RESUMO}

Esta pesquisa avaliou o potencial inseticida do extrato de folhas de Piper aduncum (L.) (Piperaceae) sobre o desenvolvimento do percevejo marrom, Euschistus heros (F.), a principal praga da soja no Mato Grosso. Para este estudo, foram realizados bioensaios com ovos, ninfas e adultos do percevejo, utilizando as concentrações de 0,5; 1,0; 2,0; 4,0 e 8,0\%, do extrato acetônico de $\boldsymbol{P}$. aduncum e como controle acetona P.A. Foram avaliados o número de ovos inviáveis, a mortalidade de ninfas e a longevidade, fecundidade e fertilidade dos adultos. No bioensaio de imersão dos ovos, todas as concentrações maiores que $1 \%$ tornou inviável mais de $70 \%$ dos ovos, enquanto, no bioensaio de contato, apenas $19 \%$ dos ovos foram inviabilizados na concentração 8\%, diferindo do controle. No bioensaio com ninfas, as concentrações de $8 \%$ e $4 \%$ ocasionaram morte de $72 \%$ e $52 \%$, respectivamente. No bioensaio com adultos, todas as concentrações testadas reduziram significativamente a sobrevivência dos insetos $e$ a reprodução dos insetos. Assim, ficou evidente que P. aduncum é uma planta com potencial para o controle do percevejo marrom, pois teve ação deletéria em todas as fases de desenvolvimento de E. heros.

Palavras-chave: pimenta-de-macaco, Euschistus heros, pragas da soja, fitoinseticida.

\section{INTRODUCTION}

In Brazil, the Neotropical brown stink bug Euschistus heros (F.) (Hemiptera: Pentatomidae) is considered a key pest in soybean crops. The damage caused by this insect is due to its feeding habit, since it feeds directly on the soybean pods, decreasing yield and grain quality (commercial product) (PANIZZI et al., 2012). In Mato Grosso, the state responsible for $28.83 \%$ of the national production of soybean (CONAB, 2013), this insect can cause losses in production of up to $30 \%$ (VIVAN \& DEGRANDE, 2011) and synthetic insecticides are often used for its control. However, the indiscriminate use of these products has contributed to environmental contamination and the selection of resistant populations of stink bugs (SOSA-GOMES \& SILVA, 2010; BELO et al., 2012).

In contrast, plants with insecticidal activity have been studied in control for insect pests because

\footnotetext{
'Departamento de Agronomia, Laboratório de Entomologia, Universidade do Estado de Mato Grosso (UNEMAT), Rodovia MT 358, Km7, 287, 78300-000, Tangará da Serra, MT, Brasil. E-mail: monica@ unemat.br *Autor para correspondência.

IIDepartamento de Ciências Biológicas, Laboratório de Entomologia, UNEMAT, Tangará da Serra, MT, Brasil. 
they generally present environmental non-persistence and a low risk of contamination in mammals (ISMAN, 2006; SANTIN et al., 2011). In this context, plants of the family Piperaceae have been investigated, mainly because of their bioactive compounds that are toxic by contact, ingestion and fumigation on insects (COITINHO et al., 2011).

The species Piper aduncum (L.) (Piperaceae) stands out for having compounds with proven insecticidal action on different orders of insects. The toxicity of this plant has been reported for insect vectors such as Aedes aegypti (L.) and Aedes albopictus Skuse (Diptera: Culicidae) (MISNI et al., 2011), in leaf-cutting ants such as Solenopsis saevissima (Smith) (Hymenoptera: Formicidae) (SOUTO et al., 2012), in coleopteran pests such as Sitophilus zeamais Motsch (Coleoptera: Curculionidae) (ESTRELA et al., 2006) and in Hemiptera such as Aetalion sp. (Hemiptera: Aetalionidae) (SILVA et al., 2007).

However, despite showing promising results in controlling various insects, little is known about the potential of this plant in controlling soybean pests. Thus, the present study aimed to evaluate the potential of the acetonic extract from leaves of $\boldsymbol{P}$. aduncum on the control of $\boldsymbol{E}$. heros in all its stages of development (egg - nymph - adult).

\section{MATERIAL AND METHODS}

Eggs, nymphs and adults of $\boldsymbol{E}$. heros used in the bioassays were obtained from a colony established at the laboratory of entomology in the "Centro de Pesquisas, Estudos e Desenvolvimento Agroambiental" (CPEDA) of the "Universidade do Estado de Mato Grosso" (UNEMAT). To obtain the extract, $\boldsymbol{P}$. aduncum plants were collected in Tangará da Serra, state of Mato Grosso (14 ${ }^{\circ} 29^{\prime} \mathrm{S}$ and $57^{\circ}$ 54'W), in December (2011) and January (2012). These plants were identified and deposited in the Tangará herbarium (TANG) (Registration nº. 1738).

For the preparation of the extract, the leaves of $\boldsymbol{P}$. aduncum were dried in a drying oven with forced air circulation for 96 hours at $37^{\circ} \mathrm{C}$, following the methodology of PRISTA et al. (1981). After drying, the leaves were ground to a vegetable powder using a knife mill with a sieve with an aperture of $1 \mathrm{~mm}$ in diameter. This powder was added to the solvent (acetone P.A.) at a ratio of $500 \mathrm{~g}$ to $1500 \mathrm{~mL}$ and allowed to percolate for seven days. Thereafter, the mixture (solvent + powder) was filtered and the solvent was evaporated by rotative evaporator to obtain the crude extract of leaves of P. aduncum.
Bioassays were conducted in a completely randomized design at concentrations of $0.5 \%, 1.0 \%$, $2.0 \%, 4.0 \%$, and $8.0 \%$ of the leaf extract of P. aduncum and acetone P.A. (control) with 10 replications per treatment. For bioassays with eggs, 30 eggs up to 24 hours old were used per repetition $(n=300$ eggs treatments $\left.{ }^{-1}\right)$; for the bioassay with nymphs, five $3^{\text {rd }}$ instar individuals were used per repetition $(n=50$ nymphs treatments ${ }^{-1}$ ); and for the bioassay with adults, one pair of $\boldsymbol{E}$. heros up to 24 hours old was used per repetition $\left(\mathrm{n}=20\right.$ adults treatments $\left.{ }^{-1}\right)$. All bioassays were conducted in a temperature-controlled room at $25.8^{\circ} \mathrm{C} \pm 3.2^{\circ} \mathrm{C}$, RH of $55.2 \% \pm 13.8 \%$, and photophase of 12 hours.

Bioassays with eggs were conducted using two methods. The first was by immersion where the eggs were dipped into the treatments for 10 seconds using an organza mesh sieve and then placed to dry on a glass surface at room temperature for 30 minutes. For the bioassay by contact, six filter paper discs of $6 \mathrm{~cm}$ in diameter were soaked with $5 \mathrm{~mL}$ of each treatment and maintained at room temperature for 30 minutes to dry. After drying, the filter paper discs impregnated with extract were individualized in Petri dishes, on which the eggs were placed. In both bioassays the number of unviable eggs in each treatment was evaluated, for a period of 10 days.

In the bioassays with nymphs and adults of $\boldsymbol{E}$. heros, $1 \mu \mathrm{L}$ (nymphs) and $5 \mu \mathrm{L}$ (adults) of the treatments were applied on the tergites of each individual kept in plastic pots $(145 \mathrm{~mL})$ with the opening sealed with organza. The pots were lined with filter paper and green-bean pods (Phaseolus vulgaris) were used for feeding the insects (COSTA et al., 1998) and changed every two days. The number of dead nymphs was recorded daily for 15 days. For adults, the survival, fecundity and fertility of females were evaluated.

Statistical analysis: The number of unviable eggs, number of dead nymphs, fertility and fecundity were submitted to a normality test (Shapiro-Wilk) and homoscedasticity of variances (Barllet). These were then subjected to a KruskalWallis one-way analysis of variance by ranks and, when significant, a multiple comparison was carried out with the Kruskal-Wallis test. For adult longevity data, the Kaplan-Meier survival analysis was performed (Gehan-Breslow) and, for the multiple comparison between the curves of each treatment, the Holm-Sidak method was used. All tests were performed at 5\% significance level. 


\section{RESULTS}

It was observed that leaves extract of P. aduncum, affected all development phases on stink bug. In the bioassay using immersion of eggs, the concentrations of $8.0 \%, 4.0 \%, 2.0 \%$ and $1.0 \%$ differed from the control resulting, respectively, in $98.0 \%, 82.7 \%, 74.3 \%$ and $16.7 \%$ of unviable eggs. In the bioassay via contact with the impregnated surface, only $19 \%$ of the eggs of $\boldsymbol{E}$. heros were unviable at the highest concentration, while the other concentrations did not differ from the control (Table 1).

In the bioassay with nymphs, after 15 days of evaluation, the extract of $\boldsymbol{P}$. aduncum led to the death of $72 \%$ and $52 \%$ of the nymphs of $\boldsymbol{E}$. heros at concentrations of $8.0 \%$ and $4.0 \%$, respectively, while the other concentrations did not differ from the control (Table 1). With adults, the extract reduced longevity and affected the reproductive potential of female E. heros at all concentrations tested, especially for concentrations of $8.0 \%$ and $4.0 \%$, in which fertility was drastically affected by the application of the extract (Table 2).

Survival analysis indicated a significant difference between the survival curves of adults (K$\mathrm{M}=109.91$, d.f. $=5$ and $\mathrm{P}>0.001)$. The survival of adults at a concentration of $8 \%$ shows the efficiency of the extract in reducing the longevity of $\boldsymbol{E}$. heros, since only $40 \%$ of the insects survived in less than 10 days and there was $100 \%$ mortality rate at 16 days of age. At a concentration of $4 \%$, survival was approximately 55 days but, despite this increased lifespan, females did lay eggs, indicating the direct effect of leaf extract of $\boldsymbol{P}$. aduncum on the reproduction of this insect (Figure 1). In other concentrations, survival varied from 86 to 92 days at low concentrations
(Figure 1) and, in these, a significant reduction was also observed in the reproductive potential of these stink bugs (Table 2).

\section{DISCUSSION}

The smaller number of viable eggs in the bioassay by contact, compared to the bioassay by immersion, is probably related to the protective effect of the chorion layers, which act as a barrier to foreign substances. The greater number of unviable eggs observed in the bioassay by immersion leads us to believe that the micropyle (structure responsible for the respiratory process in the egg) facilitates entry of the solution, thus preventing the formation of the embryo.

This hypothesis is supported by BEAMENT (1948, 1952), who reported the role of the micropyle in transporting insecticides to the interior of the egg, since the chorion is an impermeable structure for toxic substances. Although this hypothesis was not discussed by KOPPEL et al. (2011) and BROWN et al. (2012) in their research with immersion of eggs of Euschistus servus (Say), Acrosternum hilare (Say) and Nezara viridula (L.) (Hemiptera: Pentatomidae) in an insecticide solution, the authors found more than $90 \%$ of the eggs to be unviable in all chemical groups tested, indicating that these substances penetrate inside the egg and prevent development of the embryo. This effect has also been reported in eggs of Reduviidae, where the application directly on the chorion was the most successful ovicidal action in bioassays conducted by CARNEIRO et al. (2011) with Annonaceae extract on eggs of Rhodnius neglectus (Lent.) (Hemiptera: Reduviidae) with unviability of $90 \%$ of the eggs.

Table 1 - Average unviable eggs treated by the method of contact and immersion and mortality of nymphs Euschistus heros treated with leaf extract of Piper aduncum

\begin{tabular}{|c|c|c|c|c|c|c|c|}
\hline \multirow{2}{*}{ Treatments } & \multirow{2}{*}{$\mathrm{n}^{1}$} & \multicolumn{4}{|c|}{ 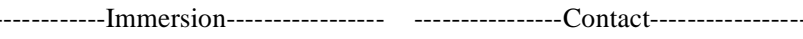 } & \multirow[b]{2}{*}{$(X \pm E P)^{2}$} & \multirow[b]{2}{*}{$\%$} \\
\hline & & $(X \pm E P)^{2}$ & $\%$ & $(\mathrm{X} \pm \mathrm{EP})^{2}$ & $\%$ & & \\
\hline $8.0 \%$ & 10 & $29.4 \pm 0.42 \mathrm{a}$ & 98.0 & $5.7 \pm 0.96 \mathrm{a}$ & 19,0 & $3.6 \pm 0.33 \mathrm{a}$ & 72 \\
\hline $4.0 \%$ & 10 & $24.8 \pm 0.87 b$ & 82.7 & $2.6 \pm 0.40 \mathrm{~b}$ & 8.7 & $2.5 \pm 0.45 b$ & 52 \\
\hline $2.0 \%$ & 10 & $22.3 \pm 1.52 b$ & 74.3 & $2.1 \pm 0.56 b$ & 7.0 & $0.4 \pm 0.21 \mathrm{c}$ & 14 \\
\hline $1.0 \%$ & 10 & $5.0 \pm 0.68 \mathrm{c}$ & 16.7 & $2.7 \pm 0.55 b$ & 9.0 & $0.8 \pm 0.27 \mathrm{c}$ & 18 \\
\hline $0.5 \%$ & 10 & $3.1 \pm 0.35 \mathrm{~d}$ & 10.3 & $2.1 \pm 0.37 b$ & 7.0 & $1.2 \pm 0.37 \mathrm{c}$ & 32 \\
\hline Acetone PA & 10 & $2.8 \pm 0.35 \mathrm{~d}$ & 9.3 & $1.2 \pm 0.29 b$ & 4.0 & $0.3 \pm 0.15 \mathrm{c}$ & 6 \\
\hline $\mathrm{H}$ & - & \multicolumn{2}{|c|}{50.68} & \multicolumn{2}{|c|}{17.43} & \multicolumn{2}{|c|}{41.36} \\
\hline
\end{tabular}

${ }^{1} \mathrm{n}=$ number of repetition for biassay (postures: 30 eggs per repetition; nymphs: 5 insects per repetition). ${ }^{2}$ Mean \pm standard error, followed by the same letter in the column do not differ by multiple comparison Kruskal-Wallis test $(\mathrm{P}>0.05)$.

Ciência Rural, v.44, n.11, nov, 2014. 
Table 2 - Longevity (days), fecundity (number of eggs) and fertility of adults Euschistus heros treated with leaf extract of Piper aduncum.

\begin{tabular}{llll}
\hline Treatments & \multicolumn{1}{c}{ Longevity $^{1}$} & Fecundity $^{2}$ & Fertility $^{2}$ \\
\hline $8.0 \%$ & $07.72 \pm 1.37 \mathrm{~d}$ & $03.80 \pm 3.80 \mathrm{~b}$ & - \\
$4.0 \%$ & $40.11 \pm 2.97 \mathrm{c}$ & - & - \\
$2.0 \%$ & $70.56 \pm 3.42 \mathrm{~b}$ & $39.70 \pm 12.19 \mathrm{~b}$ & $11.00 \pm 8.12 \mathrm{~b}$ \\
$1.0 \%$ & $75.13 \pm 3.26 \mathrm{~b}$ & $63.00 \pm 26.79 \mathrm{~b}$ & $33.50 \pm 17.53 \mathrm{~b}$ \\
$0.50 \%$ & $76.17 \pm 3.71 \mathrm{~b}$ & $28.50 \pm 13.89 \mathrm{~b}$ & $02.90 \pm 2.90 \mathrm{~b}$ \\
Acetone PA & $99.53 \pm 2.86 \mathrm{a}$ & $194.90 \pm 46.15 \mathrm{a}$ & $111.30 \pm 35.89 \mathrm{a}$ \\
$\mathrm{H}$ & - & 27.07 & 23.98 \\
\hline
\end{tabular}

${ }^{1}$ Mean \pm standard error, followed by the same letter in the column do not differ by multiple comparison Holm-Sidak $(\mathrm{P}>0.05)$. ${ }^{2} \mathrm{Mean} \pm$ standard error, followed by the same letter in the column do not differ by multiple comparison Kruskal-Wallis test (P $>0.05)$.

In this research the formation of the embryo was observed in eggs of $\boldsymbol{E}$. heros that did not hatched, but the development was prevented by the action of the extract. This was also observed in eggs of Dysdercus cingulatus (F.) (Hemiptera: Pyrrhocoridae) treated with the extract of Padina pavonica (L.) (Phaeophyceae), in which embryogenesis was interrupted after the third day of embryonic development, due to the action of the extract (SAHAYARAJ \& KALIDAS, 2011). It is believed that the leaf extract of $\boldsymbol{P}$. aduncum has this same effect on the process of embryogenesis of $\boldsymbol{E}$. heros, however, a more detailed study is necessary to determine at what stage embryogenesis is interrupted.

In nymphs of Hemiptera, despite the few studies, Piperaceae species have shown promising results, such as in Aetalion sp. treated with extract of $\boldsymbol{P}$ aduncum which, at a concentration of $30 \mathrm{mg}$ $\mathrm{ml}^{-1}(0.3 \%)$, resulted in a mortality rate of $72 \%$ of the nymphs (SILVA et al., 2007), indicating a greater susceptibility of this insect to the extract of $\boldsymbol{P}$. aduncum when compared to $\boldsymbol{E}$. heros. Besides Piperaceae, other plants with insecticidal properties have been efficient in controlling stink bug nymphs. CARNEIRO et al. (2013), when using the crude extract of $\boldsymbol{A}$. coriacea on nymphs of $\boldsymbol{R}$. neglectus, obtained a mortality rate of $80 \%$ to $93.3 \%$ in the concentrations of $100 \mathrm{mg} \mathrm{ml}^{-1}$ and $200 \mathrm{mg}$ $\mathrm{ml}^{-1}$, respectively. ABUDULAI et al. (2003), when testing a commercial product based on neem $(4.5 \%$ of azadirachtin) on the southern green stink bug $N$. viridula, observed a mortality rate of $17 \%$ and $87 \%$ of $5^{\text {th }}$ instar nymphs at concentrations of $0.5 \%$ and $5 \%$, respectively.

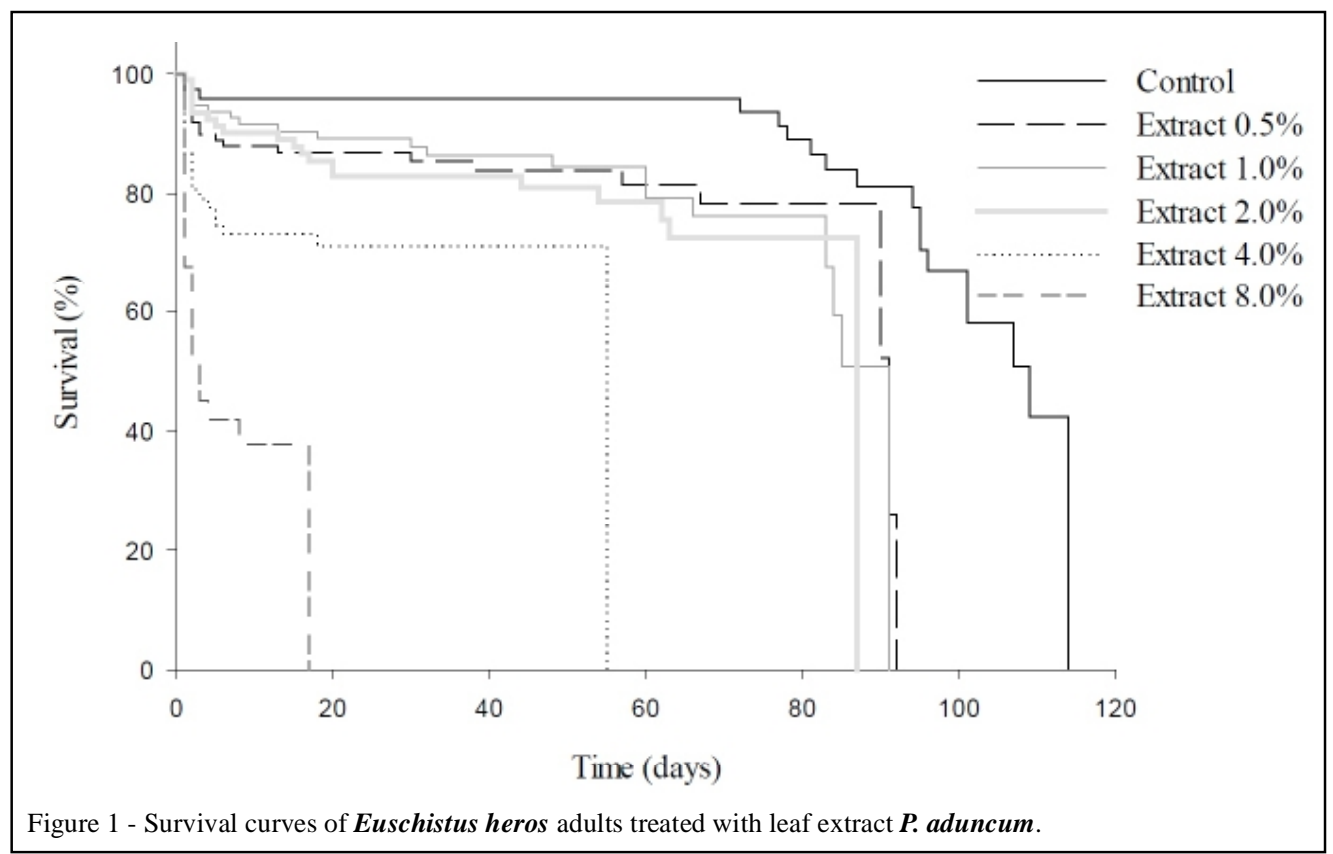

Ciência Rural, v.44, n.11, nov, 2014. 
The toxic effect of $\boldsymbol{P}$. aduncum on nymphs of $\boldsymbol{E}$. heros, is probably associated to the action of bioactive compounds present in this plant there being, among the compounds, a strong indication that dilapiolle is responsible for insecticidal activity on $\boldsymbol{E}$. heros, as reported by FAZOLIN et al. (2005), ESTRELA et al. (2006) and CELIS et al. (2008), for other insects. However, since synergism may occur between the molecules, the isolation of this compound to confirm this hypothesis is required.

The results for adults are promising, since controlling the stink bugs before they are 10 days old may reduce the number of individuals in the next generation by preventing reproductive development, because pre-oviposition period of this insect is, on average, of 10 days (SILVA et al., 2011). It is important to note that the insects that survived the concentration of $8.0 \%$ had low fertility (mean $=3.80$ eggs), differing from the control (mean= 194.90 eggs) $($ Table 2$)$.

The reduction in longevity and inhibition of oviposition of female Hemiptera adults was also observed by RIBA et al. (2003) with neem-based products containing compounds rich in azadirachtin (95\%) against the stink bug $N$. viridula. These authors relate the negative effects on the insects to the presence of the insecticide compound azadirachtin. It is worth noting that the extract of $\boldsymbol{P}$. aduncum showed results similar to those found by RIBA et al. (2003), despite its active compound not having been isolated. This highlights the potential of this plant for insect control and, therefore, research is needed to identify and isolate the active compounds, as well as to test the efficiency of these compounds in field conditions.

\section{CONCLUSION}

The species $\boldsymbol{P}$. aduncum proved to be a promising plant for promoting the control of the soybean pest, the Neotropical brown stink bug. The leaf extract of $\boldsymbol{P}$. aduncum presented an insecticidal action on eggs and nymphs of the stink bugs and affected survival, fecundity, and fertility of adults in laboratory conditions.

\section{ACKNOWLEDGEMENTS}

The authors thank the Núcleo de Educação e Ciências Tabebuia aurea (NECTAR) by financial assistence. The PROBIC (Programa de Bolsas de Iniciação Científica da Universidade do Estado de Mato Grosso) and Fundação de Amparo a Pesquisa do Estado de Mato Grosso (FAPEMAT) for providing scholarship (process no 442484/2013) and Dr. Celice Alexandre Silva by confirmation of species of Piper.

\section{REFERENCES}

ABUDULAI, M. et al. Antifeedant and toxic effects of a neem (Azadirachta indica A. Juss) based formulation Neemix against Nezara viridula (L.) (Hemiptera: Pentatomidae). Journal of Entomological Science, v.38, n.3, p.398-408, 2003.

BEAMENT, J.W.L. The penetration of insect egg-shells. In: Penetration of the chorion of Rhodnius prolixus, Stal. Bulletin of Entomological Research, v.39, p.359-383, 1948.

BEAMENT, J.W.L. The role of cuticle and egg-shell membranes in the penetration of insecticides. Annals Applied Biology, v.39, p.142-143, 1952.

BROWN, S.A. et al. Efficacy of Foliar Insecticides on Eggs of Nezara viridula (Hemiptera: Pentatomidae). Florida Entomologist, v.95, n.4 p.1182-1186, 2012. Available from: <http://dx.doi.org/10.1653/024.095.0449>. Accessed: Mar. 20, 2013. doi: 10.1653/024.095.0449.

BELO, M.S.S.P. et al. Uso de agrotóxicos na produção de soja do estado do Mato Grosso: um estudo preliminar de riscos ocupacionais e ambientais. Revista Brasileira de Saúde Ocupacional, v.37, n.125, p.78-88, 2012. Available from: <http:// dx.doi.org/10.1653/024.095.0449>. Accessed: Mar. 20, 2013. doi: $10.1653 / 024.095 .0449$

CARNEIRO, A.P. et al. Efeito biocida de Annona coriacea Mart 1841 sobre ovos e ninfas do vetor Rhodnius neglectus Lent 1954. Neotropical Biology and Conservation, v.6 n.2, p.131-136, 2011.

CARNEIRO, A.P. et al. Biocide activity of Annona coriacea seeds extract on Rhodnius neglectus (Hemiptera: Reduviidae). Revista de Biologia Tropical, v.61, n.1, p.419-427, 2013. Available from: <http://www.scielo.sa.cr/pdf/rbt/v61n1/a34v61n1.pdf>. Accessed: Mar. 18, 2013.

CELIS, A. et al. Extractos vegetales utilizados como biocontroladores con énfasis en la familia Piperaceae: una revisión. Agronomia Colombia, v.26, n. p.97-106, 2008. Available from: <http://www.scielo.org.co/pdf/agc/v26n1/v26n1a12.pdf>. Accessed: Mar. 15, 2013.

CONAB (COMPANHIA NACIONAL DE ABASTECIMENTO). Safra 2012/2013: oitavo levantamento maio/2013. Brasília 2013. Available from: <www.conab.gov.br>. Accessed: May 20, 2013.

COSTA, M.L.M; et al. Biologia reprodutiva de Euschistus heros (F.) (Heteroptera: Pentatomidae). Anais da sociedade entomológica do Brasil, v.27, n.4 p.559-568, 1998.

COITINHO, R.L.B.C. et al. Toxicidade por fumigação, contato e ingestão de óleos essenciais para Sitophilus zeamais Motschulsky, 1885 (Coleoptera: Curculionidae). Ciência e Agrotecnologia, v.35, n.1, p.172-178, 2011. Available from: <http://dx.doi. org/10.1590/S1413-70542011000100022>. Accessed: Nov. 11, 2013. doi: 10.1590/s1413-70542011000100022.

ESTRELA, J.L.V. et al. Toxicidade de óleos essenciais de Piper aduncum e Piper hispidinervum em Sitophilus zeamais. Pesquisa Agropecuária Brasileira, v.41, n.2, p.217-222, 2006. Available from: <http://www.scielo.br/pdf/pab/v41n2/a05v41n2.pdf>. Accessed: Oct. 10, 2012. doi: 10.1590/s0100-204x2006000200005.

FAZOLIN, M. et al. Toxicidade do óleo de Piper aduncum L. a adultos de Cerotoma tingomarianus Bechyné (Coleoptera: 
Chrysomelidae). Neotropical Entomology, v.34, n.3, p.485489, 2005. Available from: <http://dx.doi.org/10.1590/S1519566X2005000300018>. Accessed: Oct. 10, 2012. doi:10.1590/ S1519-566X2005000300018.

ISMAN, M.B. Botanical insecticides, deterrents, and repellents in modern agriculture and an increasingly regulated world. Annual Review of Entomology, v.51, n.1 p.45-66, 2006. Available from: <http://www.annualreviews.org/doi/pdf/10.1146/annurev. ento.51.110104.151146>. Accessed: Oct. 10, 2012. doi:10.1146/ annurev.ento.51.110104.151146.

KOPPEL, A.L. et al. Efficacy of selected insecticides against eggs of Euschistusservus and Acrosternum hilare (Hemiptera:Pentatomidae) and the egg parasitoid Telenomus podisi (Hymenoptera: Scelionidae). Journal of Economic Entomology, v.104, n.1, p.137-142, 2011. Available from: <http://dx.doi.org/10.1603/EC10222>. Accessed: Jan. 18, 2013. doi: 10.1603/EC10222.

MISNI, N. et al. The effect of Piper aduncum Linn. (Family: Piperaceae ) essential oil as aerosol spray against Aedes aegypti (L.) and Aedes albopictus Skuse. Tropical Biomedicine, v.28, n.2, p.249-258, 2011.

PANIZZI, A.R. et al. Insetos que atacam vagens e grãos. In: HOFFMANN-CAMPO, C.B.; et al. Soja: manejo integrado de pragas e outros Artrópodes-pragas. Brasília: EMBRAPA, 2012. Cap.5. p.335-420.

PRISTA, L.N. et al. Técnica farmacêutica e farmácia galênica. Lisboa: Calouste Gulbenkian, 1981. V.1. 147p.

RIBA, M.J. et al. Influence of azadirachtin on development and reproduction of Nezara viridula L. (Het., Pentatomidae). Journal Applied Entomology, v.127, p.37-41,2003. Available from: <http:// onlinelibrary.wiley.com/doi/10.1046/j.1439-0418.2003.00684.x>. Accessed: Oct. 10, 2012. doi: 10.1046/j.1439-0418.2003.00684.x.

SAHAYARAJ, K.; KALIDAS, S. Evaluation of nymphicidal and ovicidal effect of a seaweed, Padina pavonica (Linn.) (Phaeophyceae) on cotton pest, Dysdercus cingulatus
(Fab.). Indian Journal of Marine Sciences, v.40, n.1, p.125-129, 2011. Available from: <http://nopr.niscair.res.in/ bitstream/123456789/11381/1/IJMS\%2040\%281\%29\%20125129.pdf>. Accessed: Mar. 23, 2013.

SANTIN, J.R. et al. Evaluation of the acute toxicity, genotoxicity and mutagenicity of ethanol extract of Piper aduncum. Journal of Medicinal Plants Research, v.18, n.5, p.4475-4480, 2011. Available from: <http://www.academicjournals.org/jmpr/pdf/ pdf2011/16Sept/Santin\%20et\%20al.pdf $>$. Accessed: Mar. 26, 2013.

SILVA, F.A. et al. Survivorship and egg production of phytophagous pentatomids in laboratory rearing. Neotropical Entomology, v.40, n.1, p.35-38, 2011. Available from: <http://dx.doi.org/10.1590/ S1519-566X2011000100005>. Accessed: Mar. 15, 2013. doi: 10.1590/S1519-566X2011000100005.

SILVA, W.C. et al. Atividade inseticida de Piper aduncum L. (Piperaceae) sobre Aetalion sp. (Hemiptera: Aetalionidae), praga de importância econômica no Amazonas. Acta Amazônica, v.37, n.2, p.293-298, 2007. Available from: <http://dx.doi.org/10.1590/ S0044-59672007000200017>. Accessed: Mar. 15, 2013. doi: 10.1590/s0044-59672007000200017.

SOSA-GÓMEZ, D.R.; SILVA, J.J. Neotropical brown stink bug (Euschistus heros) resistance to methamidophos in Paraná, Brazil. Pesquisa Agropecuária Brasileira, v.45, n.1, p.767769, 2010. Available from: <http://dx.doi.org/10.1590/S0100204X2010000700019>. Accessed: Mar. 23, 2013. doi: 10.1590/ S0100-204X2010000700019.

SOUTO, R.N.P. Insecticidal activity of Piper essential oils from the amazon against the fire ant Solenopsis saevissima (Smith) (Hymenoptera: Formicidae). Neotropical Entomology, v.41, n.6, p.510-517, 2012. Available from: <http://link.springer.com/article /10.1007\%2Fs13744-012-0080-6>. Accessed: Apr. 16, 2013. doi: 10.1007/s13744-012-0080-6.

VIVAN, L.M.; DEGRANDE, P.E. Pragas da soja. Fundação MT Boletim de Pesquisa de Soja, v.11, p.239-297, 2011 